\title{
A Bulb of Narcissus on the Egyptian Mummy from University of Wroclaw Collection
}

\author{
KrzyszTof BorysŁawski, AnNa NiwińsKa, AndrzeJ NiwińsKi, \\ AgNIESZKA TOMASZEWSKA, KRYSTYNA WASYLIKOWA, \\ AGNIESZKA ŻELAŹNIEWICZ
}

\begin{abstract}
The object of the present study is the ancient bulb of the narcissus found on the mummy, probably of the Ptolemaic period, brought to Wrocław from Italy in the sixteenth century AD. For about four hundred years the mummy was kept by the successive owners of one of pharmacies in Wrocław, and after the World War II became the possession of Wrocław University. Computed tomography made in 2002 revealed an atypical object lying under the left hand of the mummy. Extracted in 2004 it appeared to be the bulb of a flower, and botanical analysis has revealed that it represents the Narcissus tazetta L. species. Although the narcissus was known in Egypt, its identification in the ancient sources has never been attempted. Thanks to the analysis of the bio-medical properties of the narcissus, compared with some descriptions of remedies proposed by the medical papyri Ebers and Hearts, as well as with some religious magical texts an identification of the sennut plant with narcissus is proposed here.
\end{abstract}

Keywords: Ptolemaic Egypt, Egyptian mummy, flower bulb, Narcissus tazetta L., medical papyri, Nefertum

Krzysztof Borysławski, Department of Anthropology, Wrocław University of Environmental and Life Sciences, Wrocław; krzysztof.boryslawski@upwr.edu.pl

Anna Niwińska, Center for Biomedical Research, Faculty of Veterinary Medicine, Warsaw University of Life Sciences, Warszawa; niwianna@gmail.com

Andrzej Niwiński, Department of Egyptian and Nubian Archaeology, Institute of Archaeology, University of Warsaw, Warszawa; andrzejniwi.egipt@gmail.com

Agnieszka Tomaszewska, Department of Anthropology, Wrocław University of Environmental and Life Sciences, Wrocław; agnieszka.tomaszewska@upwr.edu.pl

Krystyna Wasylikowa, Department of Palaeobotany, Władysław Szafer Institute of Botany, Polish Academy of Sciences, Kraków

Agnieszka Żelaźniewicz, Department of Human Biology, University of Wrocław, Wrocław;

agnieszka.zelazniewicz@uwr.edu.pl

The aim of this study is to present and discuss the atypical results obtained during the investigation of a mummy in possession of the Department of Anthropology of Wroclaw University, Poland. The mummy was brought from Egypt through Italy in the sixteenth 
century AD, and was exposed, together with two other mummies, in the cabinet of curiosities belonging to Laurentius Scholz von Rosenau, a medic and botanist living in Wrocław in the years 1552-1599. The pavilion with the cabinet of curiosities was situated within the area of the botanical garden founded by the city in 1588 and known as Hortus Scholzianus. After the death of Scholz the garden including the cabinet of curiosities was purchased by the pharmacist Christian Krause (Crusius), and later inherited by his son, the medic and pharmacist Jacob, owner of the 'Pharmacy under Neger' ('Mohren-Apotheke') situated until today at the Solny Place, Wrocław.

In 1658 the renowned man of letters and scientist Andreas Gryphius (1616-1664), then holding the high function in the administration of Głogów and having good relations with members of the city council in Wrocław, was successful in arranging the agreement of Jacob Crusius to perform an autopsy of one of the mummies. This event took place on the $7^{\text {th }}$ December 1658, probably in the old garden pavilion, in the company of a number of high positioned citizens of Wrocław. The results of the autopsy were published in 1662 in a book edited by Vitus Jacobus Dreschers editorial house in Wrocław. ${ }^{2}$ Some of the observations made on the mummy and the mummification process are most interesting. The skull was found torn off from the vertebral column, and, after the brain had been removed, fixed on a wooden stick. Under one foot of the mummy a flower was found, either a lotus or onion. ${ }^{3}$ The mummy can probably be dated to the Ptolemaic or Roman period, because of the position of hands crossed over the breasts (Fig. 1) and the finding of a golden leaf, comparable perhaps to an object in the Pelizeaus Museum in Hildesheim. ${ }^{4}$ After the autopsy the investigated mummy was sold to the city councilor Jan Christian von Wolfsburg, then to another city councillor Godfrey Springer, and finally it was handed, in 1717, to rector Christian Stieff as a gift to the library in Wrocław. The mummy is now lost.

The second mummy owned by Jacob Crusius was in the time of the autopsy already only in a fragmentary state, having probably been used by the pharmacist as the source of production of the 'healing' powder known as mummia Aegyptiaca vera, highly esteemed in those days. ${ }^{5}$

The third mummy, the object of this study, remained intact in the above mentioned pharmacy in Wrocław, serving to appeal the potential customers and even also a kind of the pharmacist's identification mark. The signs and hieroglyphs found on the mummy's exterior

1 Śliwa 2012: 369-370.

2 Gryphius 1662.

${ }^{3}$ Gryphius 1662: 38; Śliwa 2012: 375.

${ }^{4}$ On the position of hands of mummies, cf.: Gray 1972: 200-202 (with the conclusion that the arms crossed upon the breast prevail in Ptolemaic period); Ikram, Dodson 1998: 130 (with the conclusion that such a position of the arms prevails in the Roman period). The multi-part type cartonnages appear on mummies dated from the latest dynastic to the Roman period cf.: Myśliwiec, Herbich, Niwiński 1995: 195. A comparable material concerning Ptolemaic mummies originates from the Polish excavations at Saqqara, cf.: Kaczmarek et al. 2008; Radomska et al. 2008. The golden object in the form of the tongue, similar to that from Wrocław, was published by Germer 1988: 25 (dated to the Roman period).

${ }^{5}$ Geßler-Löhr 1998: 109-110; Urbanik, Rzepiela 2002: 572-579; Tomaszewska et al. 2012: 59. 
1. Mummy having been the object of the autopsy in Wrocław in 1658 (Gryphius 1662: 40).

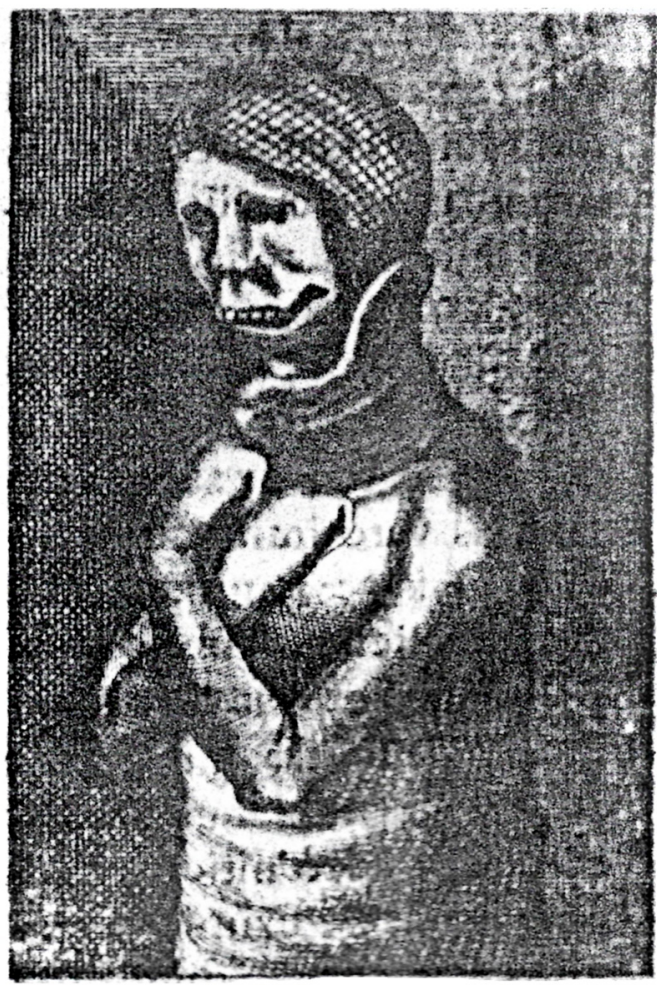

were practically illegible, and the mummy was blackened. ${ }^{6}$ After the end of the World War II the mummy was handed to the Department of Anthropology, Wrocław University. Placed in a glass case, covered with a piece of modern ornamented fabric, and crowned with a tin cap (Fig. 2) the mummy soon was given the nickname 'Snow White' by school children visiting the exposition of the department. ${ }^{7}$ Its original nature has been forgotten, and the body was then misinterpreted as a 'false mummy' or 'mummy of a townswoman of the eighteenth century AD'. It was only in May 1979 when the true nature of the object was detected by an Egyptologist, and in 1981 the mummy was X-rayed in the Department of Radiology of the Medical Academy, Wrocław, by Zdzisława Bem and Tadeusz Krupiński. The results made possible some important observations. ${ }^{8}$

\footnotetext{
${ }^{6}$ Śliwa 2012: 373.

${ }^{7}$ According to the letter of $9^{\text {th }}$ June 1979 from Wanda Stęślicka, Department of Anthropology, University of Wrocław, to Andrzej Niwiński.

${ }^{8}$ These have been described in the letter of $15^{\text {th }}$ February 1981 from Tadeusz Krupiński, Department of Anthropology, Wrocław University, to Andrzej Niwiński.
} 


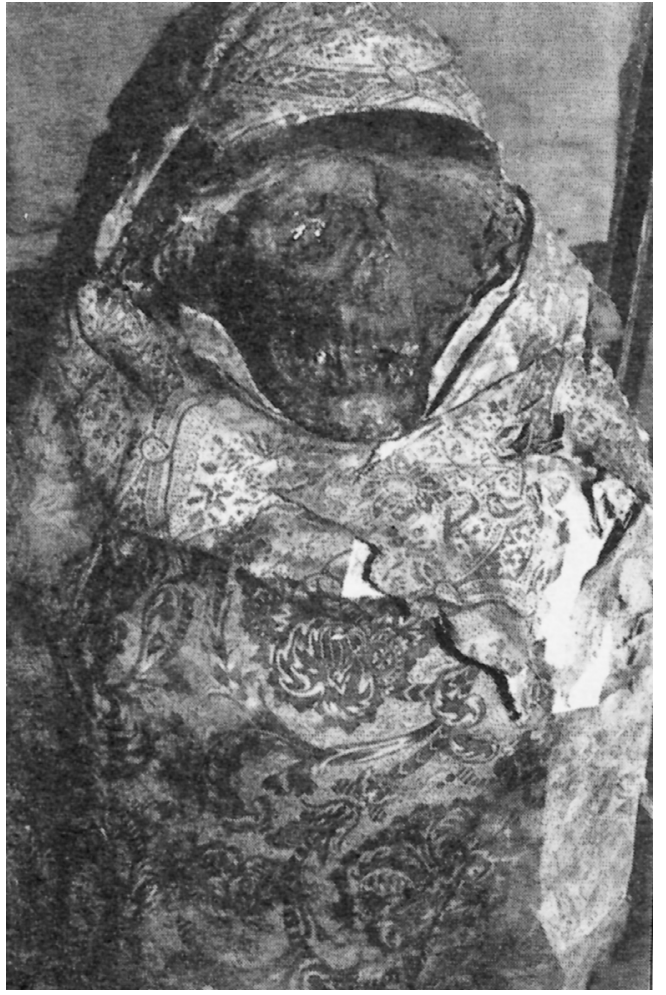

2. Mummy in the Department of Anthropology of the University of Wrocław, prior to 1981 (Phot. J. Śliwa).

\section{RADIOLOGICAL INVESTIGATIONS OF THE MUMMY}

The mummy belongs to a young adult woman aged 21-23 years, with the arms crossed over the breasts, the left forearm lying above the right one. No metallic objects have been detected; other objects could not be seen on the X-ray image. The position of the hands supports dating of the mummy to the Late period or the Ptolemaic period (seventh-first centuries BC); the Roman period cannot be excluded, either. More data were expected from the computed tomography analysis that could, however, be made only in 2002 by Andrzej Urbanik from the Chair of Radiology, Jagiellonian University Medical College, Cracow. On $26^{\text {th }}$ September 2002 the results obtained by the tomography were discussed in Wrocław. ${ }^{9}$ Some 752 cross-sectional pictures in the transverse plane of the mummy were made. Cross-sectional images were analysed with the use of SIENET Magic View 300 software. ${ }^{10}$ The type of material in particular layers was evaluated, based on Hounsfield units (HU). All measurements were performed with the use of Materialise Mimics 10.01 and SIENET Magic View 300 software. The analysis has revealed that the skull

\footnotetext{
9 By Krzysztof Borysławski, Tadeusz Krupiński, Andrzej Niwiński, Andrzej Urbanik.

10 Borysławski 2009: 200-202.
} 


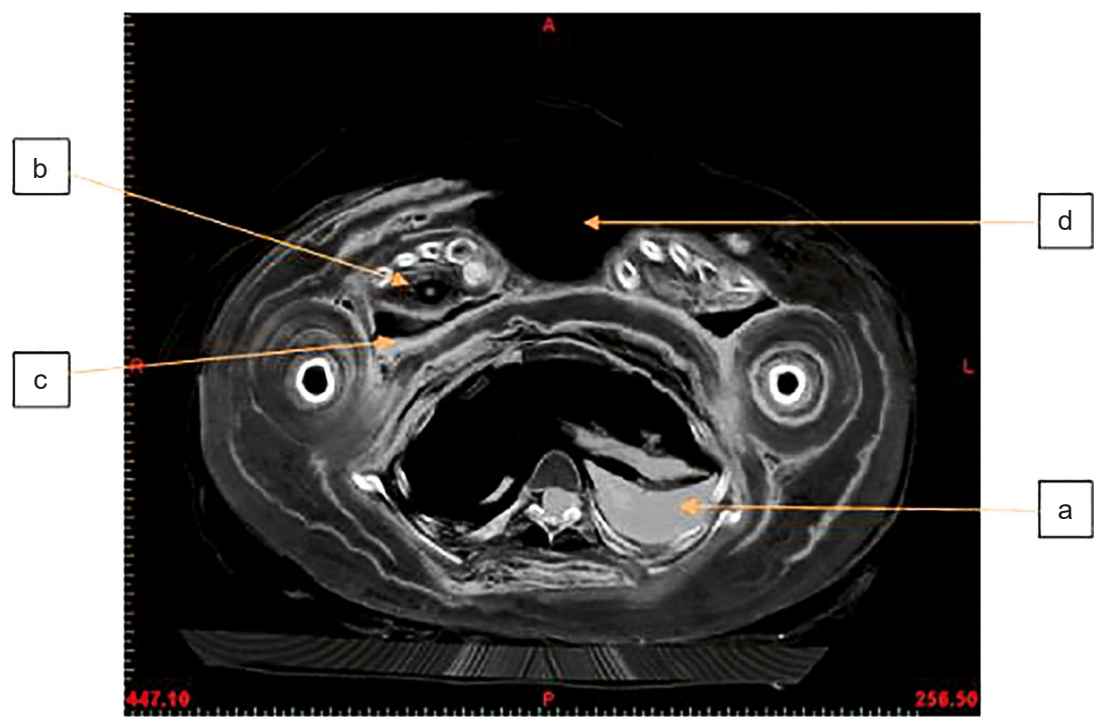

3. Cross-section through the upper torso at the level of thoracic vertebra 3: a. resin mat; b. narcissus bulb; c. a layer of bandages soaked in resin; d. damage of the bandages (image from the computed tomography done by A. Urbanik in 2002, Cracow).

and spinal canal were filled with resin. Additionally a material of high density (HU 3000), typical for metals, was discovered in the orbits and over the nasal bones, which may contradict the results of the X-ray. It seems that the lowest part of the mummy, beneath the knees, was enveloped separately, and then fixed with two long (over $20 \mathrm{~cm}$ in length) wooden pegs of square section ( $2 \mathrm{~cm}$ of width). Two thin long objects, possibly made of rolled linen, lay upon the shins, which constitutes an analogy to the similar cord-like linen objects discovered on the mummy of Ptolemaic period in the Archaeological Museum, Cracow. ${ }^{11}$ Finally, under the left hand reposing on the breast an undetermined oblong object was detected, which was situated near a damaged part of bandages, probably caused by the ancient robbers, and therefore was easy to extract (Fig. 3). The act of the extraction took place on the $21^{\text {st }}$ September 2004 in Wrocław, during which the flower bulb that is the subject of this paper was found (Fig. 4). Additionally, in 2004 the restoration of the intravital appearance of the mummy's head and face was performed. The 3D model was created with the use of the epoxide resin basing on the computed tomography images at the Rapid Prototyping / Rapid Tooling Laboratory in the Institute of Production Engineering and Automation, Wrocław University of Technology. ${ }^{12}$

\footnotetext{
11 Niwiński 1998: 186, P1. 1.1; Urbanik 2001: 79-83.

12 Borysławski 2009: 200; Tomaszewska et al. 2012: 61.
} 


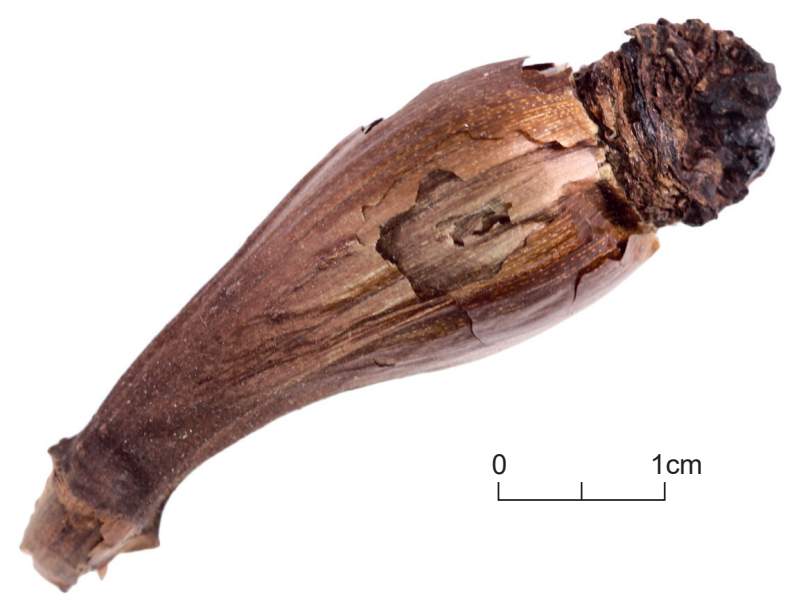

4. The present appearance of the bulb of the Narcissus tazetta L. extracted from the mummy in 2004 (Phot. D. Nowakowski).

\section{PLANT BULBS ON EGYPTIAN MUMMIES}

The most common finds of such objects represented the species of onion (Allium cepa) and garlic (Allium sativum). The bulbs were used during the embalmment process and were placed, for example, in orbits. ${ }^{13}$ The flower bulbs, however, were often discovered on mummies, too. Bulbs of an unidentified flower were found on the mummy of Ramesses IV, imitating his eyes, and placed also in the pharaoh's nostrils. ${ }^{14}$ Flowers were often used to decorate mummies (Fig. 5), ${ }^{15}$ and bulbs of flowers were discovered in some mummies under the bandages. For instance, Thomas Joseph Pettigrew discovered 'bulbous roots' placed under the soles of both feet of a mummy, probably of the Late period, ${ }^{16}$ and a similar discovery of a 'bulbous root', albeit only under one foot, was made in $1764 .{ }^{17}$

During the investigations of the Twenty first Dynasty mummies of the priests of Amon and their wives, originating from the Bab el-Gusus tomb at Deir el-Bahari, Georges Daressy made the following observations; mummy no. 82 (man): sous l'oudja en cire étaient des oignons, probablement de fleurs, ainsi que sous les pieds et les mains $;{ }^{18}$ mummy no. 120 (man): au-dessous de la plaque de cire étaient posées des feuilles, d'autres pétals de lotus et des onions étaient placés sous les pieds et le long des jambes $;{ }^{19}$ mummy no. 127 (woman): sur la poitrine avaient été placés des oignons de fleurs, ${ }^{20}$ mummy no. 139 (woman): au

\footnotetext{
13 Germer 1988: 42.

14 Smith 1912: 88.

15 Schweinfurth 1884: 628-629; Drenkhahn, Germer 1991: 99-104.

16 Pettigrew 1834: 102.

17 Granville 1825: 282.

18 Daressy 1907: 29.

19 Daressy 1907: 32.

20 Daressy 1907: 34.
} 


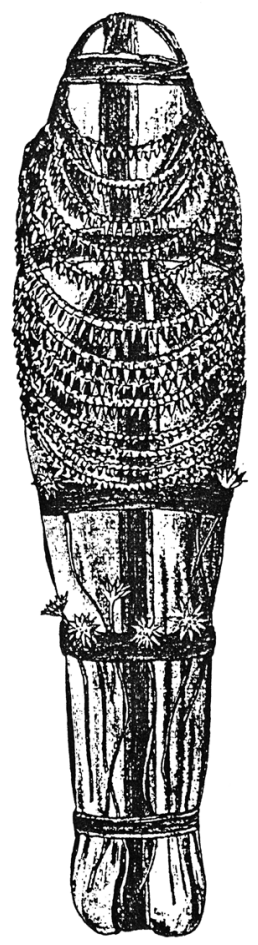

5. Mummy decorated with the flowers and floral garlands (Schweinfurth 1884: 628).

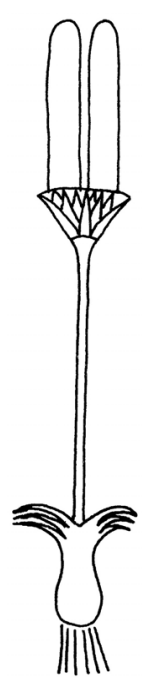

6. The image of the plant of Nefertum carved on an Egyptian sarcophagus (Drawing: A. Niwiński; based on: Naville 1910: P1. II).

cou se trouvaient (des amulettes) ainsi qu'un oignon de lys. ${ }^{21}$ Although only a general identification of an 'onion'/“bulb' was usually made during the autopsies done in the seventeenth-early twentieth centuries $\mathrm{AD}$, modern research of the remains of a bulb found on the neck of Ramesses II's mummy has identified this with Narcissus tazetta L. (cf.). ${ }^{22}$ This is supported by the discovery on the Wrocław mummy, making it theoretically possible that many of the flower bulbs found earlier on mummies may have represented the narcissus species, as well.

\section{AN ATTEMPT AT THE IDENTIFICATION OF THE ANCIENT NAME OF NARCISSUS}

This hypothesis may perhaps be corroborated by the herbal of Dioskorides Pedanius from the first century AD. He noted that the bulb of narcissus cooked and eaten provoked vomiting, and that fresh bulbs laid on the skin healed burns and open wounds. ${ }^{23}$ This may

\footnotetext{
21 Daressy 1907: 36.

22 Germer 1988: 9, 13; after Layer-Lescot 1985.

23 Germer 1998: 2.
} 
explain the meaning of the above mentioned cases of the scale leaves of a bulb as posed directly on the incisions on some mummies, described by Daressy. Unfortunately, it has so far been impossible to identify the ancient Egyptian word meaning narcissus, and one can quote here Renate Germer's opinion: So kommt es, daß wir zwar aus botanischen Funden wissen, daß auch die Ägypter die Narcisse kannten, denn Reste von NarcissenZwiebelschalen fanden sich an der Mumie Ramses II, doch haben wir keine Möglichkeit, ihre Namen zu identifizieren, der sicher in einigen dieser Rezeptur-Auflistungen vorkommt. ${ }^{24}$

It seems plausible to propose such an identification here. Edouard Naville long ago published a ritual text, carved on a stone found in 1886 in Horbeit (the ancient Egyptian Pharbaethus near Abu Kebir in the eastern Delta). The text was illustrated with an image of a plant (Fig. 6) with its flower similar to a lotus, and crowned with two high feathers, which presented the sacred emblem of Nefertum, and was accompanied by the following words translated by Naville: Il est grand celui-ci qui sort de la terre humide /.../ la grande puissance qui Keb a mise au monde et qui arrête Set dans sa fureur. ${ }^{25}$ Naville has then found a number of other sources containing the same ritual text, where the name of the plant appears, among other in the Theban Tomb 39 of Puimre: il est grand celui qui sort de la terre, le sennu issue de Nout, du ciel. ${ }^{26}$

Regardless of the religious-magical meaning of this plant, glorified as very much efficient for the dead as a weapon of Nefertum, compared sometimes to a terrible lion, its physical features can be deduced from the illustration on the stone from Horbeit, and from the texts, the most useful of which are the medical papyri Ebers (P.Eb. 294) and Hearst (H.35): the plant the name of which is senutet. It grows from its bulb /.../ and makes the flowers like those of lotus. ${ }^{27}$ The plant sennu (or sennut, sennutet) is growing from a bulb planted in (humid) earth, and its flower resembles lotus. Naville makes, however, a very correct note in this respect: cette fleur quiqu'elle s'appelle un lotus, n'est pas celle que les naturalistes désignent par le nom de lotus. Leur [= Egyptian] classifications reposent sur l'apparence générale. Ainsi le sennu peut être appelé "lotus », ce qui veut dire plante ayant une fleure du genre de celle du lotus. ${ }^{28}$ Therefore, the suggestions of Victor Loret ${ }^{29}$ and Thierry Bardinet ${ }^{30}$ identifying the sennut plant with blue lotus are not correct, since only a physical resemblance of the flower with lotus is mentioned in the papyri Ebers and Hearst, and the lotus is not growing from a bulb. Édouard Naville ${ }^{31}$ and Andrzej Niwiński ${ }^{32}$ suggested that the plant may perhaps be identified with a lily. The identification with narcissus seems, however, much more plausible, not only because of the physical similarities (the bulb, the strongly fragrant flower with white petals and yellow centre), but also

\footnotetext{
24 Germer 1998: 3.

25 Naville 1910: 191, Pl. II.

26 Naville 1916: 188.

27 Bardinet 1995: 125-128.

28 Naville 1916: 188-189.

29 Naville 1927: 34.

30 Bardinet 1995: 296, 379.

31 Naville 1927: 34.

32 Niwiński 1998: 189.
} 
because of the biological properties and medical use of the narcissus. A mere observation that the cut flowers of narcissus inserted into a vase together with other flowers make very soon withering process of these, indicates a strong (toxic) interaction of this plant. Both medical papyri make it an efficacious remedy against setet, supposed by the ancient Egyptians to be a kind of dangerous being living in the ill body. These setet should have been banished alive,,$^{33}$ and to this purpose the leaves of the sennut plant were used, rubbed in the lower abdomen of the sick person. The description of the bio-medical properties of narcissus (cf. Appendix 2) points both to the fact that the various parts of the narcissus plant can be effectively used in the modern medical treatment, and that these are still used in the native African medicine, which supports the observation that ancient Egyptians may have applied narcissus similarly in the daily life.

The creative thought of Ancient Egyptians made, at the same time, the sennut plant, thus most probably the narcissus, an efficacious talisman for the dead as a symbol of resurgent life. Mythically identified with Nefertum, the plant could be represented on a coffin, sarcophagus, or in a wall painting, and the bulbs, leaves and flowers of narcissus were laid on the body of the deceased. Those objects were supposed to protect the dead from evil and ensure him/her supernatural forces. One can quote here again Naville, who devoted to Nefertum and his magical plant a special study: la plante sert de talisman assurant, soit au corps du défunt, soit aux offrandes qu'on déposait à côté de lui, une protection efficace contre ses ennemies, dont le premier devait sans doute être la corruption. Il suffisait de représenter la plante pour la faire naître ; peut-être aussi en mettait-on un spécimen dans le tombeau. ${ }^{34}$

The growing plant could as well be imitated in linen, what was observed on the Ptolemaic mummy in Cracow, ${ }^{35}$ and seems to be also the case on the Wrocław mummy. The placing, on the same mummy, of the narcissus bulb under its hand was another means of protection of the body against the 'fury of Set'.

\section{APPENDIX 1: THE BOTANICAL ANALYSIS OF THE BULB}

Roentgen imaging and computed tomography revealed an atypical structure under the left hand of the mummy (cf. Fig. 3). Due to the lesions in the upper torso area the artefact was extracted in order to conduct detailed analysis. The placement of the artifact allowed avoiding damage during the extraction. The artefact was recognised as a flower bulb.

The macroscopic analysis has revealed that the bulb was slightly bent, its length was $5.5 \mathrm{~cm}$, and the maximum width was $1.6 \mathrm{~cm}$ and minimum width (at the apex) was $1.1 \mathrm{~cm}$ (cf. Fig. 4). The observed curve suggests that it was a side bulb of a flower. At the bottom of the bulb there is a basal plate with remains of the scales. In the upper part of the bulb, the external leaf is slightly thicker than the other scales, which are thin and fragile. The size and shape of the bulb are similar to the subspecies of narcissus and iris which develop bulbs.

\footnotetext{
33 Bardinet 1995: 125-128.

34 Naville 1927: 44.

35 Niwiński 1998: 182, 186-187.
} 
The microscopic analysis revealed that the scales of the bulb exhibit a thigh cellular structure, and traces of spawn of fungi are visible between the cells. The vascular bundles with visible spiral thickenings are well preserved. There are two types of the thickenings in the vascular system: most are narrow, with close torsions, and some are thicker, with a wide torsions. In the external cell layer the needle-shaped crystals (raphides) are visible, mostly arranged along the vascular bundles. In some areas the raphides are arranged in a chaotic manner.

The anatomy of the scale leaves of the bulb has been compared to the scale leaves of the onion Allium cepa L., garlic Allium sativum L., narcissus Narcissus tazetta L., Narcissus sp., iris Iris Bucharina M. Foster, and Iris sp. The spiral thickenings in the vascular system, similar to those observed and analysed bulb from the Egyptian mummy, are present in narcissus and iris species, but the shape of raphides in this bulb is more typical for the narcissus species. The analysed flower bulb is probably a bulb of Narcissus tezetta L. (cf.), as it was the only narcissus species growing wild in the north part of Egypt. Nowadays the Narcissus tazetta L. (cf.) is commonly growing in gardens, which is a tradition since Graeco-Roman period. ${ }^{36}$

\section{APPENDIX 2: THE BIO-MEDICAL PROPERTIES OF NARCISSUS}

Narcissus tazetta L. belongs to the Amaryllidaceae family and is a type of daffodil. Plants from this family have been used for centuries in the Mediterranean area ${ }^{37}$ and by African tribes as medicinal herbs (see also below). Poultices and decoctions based on bulbs and leaves from this plant family have been used in traditional African medicine against abdominal pains and indigestions. The African tribe Zulu also uses rhizomes from daffodils as amulets against evil forces. In higher doses substances contained in Amaryllidaceae are very toxic and often used as potent narcotics, or even poison.

From historical sources it is known that the anticancer properties of Narcissus sp. were already realised by the 'father of the medicine' Hippokrates of Kos (c. 460-370 BC) who recommended a pessary prepared from narcissus oil for the treatment of uterine tumours. The application of narcissus oil in cancer treatment continued in the Middle Ages in Chinese, North African, Central American and Arabian medicine. ${ }^{38}$

Modern medicine derives from traditional methods. Thanks to the advanced biochemistry many substances such as flavonoids, glycosides, phenolics, and the most important - alkaloids have been found as occurring in the plants of this family. Alkaloids are bioactive substances that may strongly affect the human organism. Alkaloids exuded by the Amaryllidaceae family exhibit diverse effects on the human body, such as analgesic or tranquilising effects, anticancer capabilities, or even antibacterial, antiviral and antifungal effects. Some of these alkaloids inhibit malaria (Plasmodium falciparum) development. ${ }^{39}$ Substances isolated from the Narcissus tazetta L. species exhibit antiviral effects, especially potent against Choriomenigitis virus that causes a type of aseptic

\footnotetext{
36 Täckholm, Drar 1973: 348.

${ }^{37}$ Saad, Said 2011: 239.

38 Jin 2013: 481; Chegaing Fodouop et al. 2015: 11.

39 Jin 2013: 512-513.
} 
meningitis. ${ }^{40}$ Other, alkaloids, for example galanthamin and lycorin, are successfully tested and used as selective acetylcholinesterase inhibitors in Alzheimer's disease patients. Recently, antineoplastic effects of the substances mentioned above have been focused on, and should be tested soon. ${ }^{41}$

To sum up, the alkaloids from the Narcissus tazetta L. exhibit strong effects of analgesia, parasymphatetic stimulation (AChE inhibition), antibacterial effects, stimulation of the own immune system of the body, and also tranquilising and anti-depression effects. With this in mind, it seems highly possible that poultices made from the leaves of the Narcissus tazetta $L$. and applied on the stomach may exhibit analgesia, and through the stimulation of the parasympathetic nervous system, also the peristalsis may be prompted, which could help in the abdominal pain and indigestions treatment. Due to biostatic and immune-stimulating effects of this kind of treatment even bacterial and viral infections can be inhibited or cured. On the other hand, some potent toxic effects - the substances contained in those plants may provoke: dementia, vomiting, headaches or even hallucinations - may have created the idea of the dangerous 'power' of those plants. All this seems to confirm the possible connection between the Narcissus tazetta L. and the ancient Egyptian sources, including the medical papyri Ebers and Hearst.

\section{References}

Bardinet, T. 1995: Les papyrus médicaux de l'Égypte pharaonique, Paris

Borysławski, K. 2009: Badanie mumii egipskiej z wykorzystaniem tomografii komputerowej, [in:] Dzieduszycki, W., Wrzesiński, J. (Eds), Metody. Źródła. Dokumentacja, Funeralia Lednickie 11, Poznań, 199-203

Chegaing Fodouop, S.P., Tagne Simo, R., Mbo Amvene, J., Talla, E., Seke Etet, P.F., Takam, P., Nwabo Kamdje, A.H., Muller, J.-M. 2015: Bioactivity and Therapeutic Potential of Plant Extracts in Cancer and Infectious Diseases, Journal of Diseases and Medicinal Plants $\mathrm{I} / 1,8-18$

Daressy, G. 1907: Cercueils des prêtres d'Ammon (Deuxième Trouvaille de Deir el-Bahari), ASAE VIII, 3-38

Drenkhahn, R., Germer, R. 1991: Mumie und Computer: Ein multidisziplinäres Forschungsprojekt in Hannover, Hannover

Germer, R. 1988: Katalog der altägyptischen Pflanzenreste der Berliner Museen, Wiesbaden

Germer, R. 1998: Neue Ansätze zur Identifizierung altägyptischer Heilpflanzen (habilitation lecture on 28. 04. 1998), Hamburg

Geßler-Löhr, B. 1998: Mumia vera aegyptiaca im Abendland, [in:] Fitzenreiter, M., Loeben, C.E. (Eds), Die ägyptische Mumie, ein Phänomen der Kulturgeschichte, IBAES 1, London, 109-110

Granville, A.B. 1825: An Essay on Egyptian Mummies, with Observations on the Art of Embalming among the Ancient Egyptians, PTRS, London, 269-316

\footnotetext{
${ }^{40}$ Kornienko, Evidente 2008: 1986.

${ }^{41}$ Kornienko, Evidente 2008: 1982-1987; Jin 2013: 514.
} 
Gray, P.H.K. 1972: Notes concerning the position of arms and hands of mummies with a view to possible dating of the specimen, JEA 58, 200-204

Gryphius, A. 1662: Mumiae Wratislavienses, Wrocław

Ikram, S., Dodson, A. 1998: The Mummy in Ancient Egypt. Equipping the Dead for Eternity, London

Jin, Z. 2013: Amaryllidaceae Alkaloids, [in:] Ramawat, K.G., Mérillon, J.-M. (Eds), Natural Products - Phytochemistry, Botany and Metabolism of Alkaloids, Phenolics and Terpenes, Heidelberg, 479-522

Kaczmarek, M., Schweitzer, A., Godziejewski, Z., Pannenko, I. 2008: The Upper Necropolis II: Studies and photographic documentation, Ed. Myśliwiec, K., Saqqara III, Varsovie Kornienko, A., Evidente, A. 2008: Chemistry, Biology and Medicinal Potential of Narciclasine and Its Congeners, Chemical reviews 108/6, 1982-2014

Layer-Lescot, M. 1985: Feuilles et fleurs, [in:] Balout, D., Roubet, C. (Eds), La momie de Ramsès II, Paris, 182-195

Myśliwiec, K., Herbich, T., Niwiński, A. 1995: Polish Research at Saqqara in 1987, EtudTrav XVII, 177-203

Naville, E. 1910: La plante de Horbéit, ASAE X, 191-192

Naville, E. 1916: La plante de Horbéit II, ASAE XVI, 187-190

Naville, E. 1927: La plante magique de Neferatum, Revue de l'Égypte Ancienne 1, 31-44

Niwiński, A. 1998: Some unusual amulets found on the Late Period mummies in Warsaw and Cracow, [in:] Clarysse, W., Schoors, A., Willems, H. (Eds), Egyptian Religion, the last thousand years I. Studies dedicated to the memory of Jan Quaegebeur, Leuven, 179-190

Pettigrew, T. 1834: History of Egyptian Mummies, London

Radomska, M., Kowalska, A., Kaczmarek, M., Rzeuska, T.I with contributions by Kopp, E., Kuraszkiewicz, K.O., Winnicki, J.K. 2008: The Upper Necropolis I: The Catalogue, Saqqara III, Ed. Myśliwiec, K., Varsovie

Saad, B., Said, O. 2011: Greco-Arab and Islamic Herbal Medicine. Traditional system, ethics, safety, efficacy, and regulatory issues, Hoboken-New Jersey

Schweinfurth, G. 1884: Der Blumenschmuck ägyptischer Mumien, Die Gartenlaube 38, Leipzig, 628-630

Smith, G.E. 1912: The Royal Mummies. Catalogue Général des Antiquités Égyptiennes du Musée du Caire Nos 61051-61100, Cairo

Śliwa, J. 2012: Andreas Gryphius (1616-1664) i mumie egipskie we Wrocławiu, [in:] Śliwa, J., Badacze, kolekcjonerzy, podróżnicy, Cracow, 365-380

Täckholm, V., Drar, M. 1973: Flora of Egypt 3, Königstein im Taunus

Tomaszewska, A., Żelaźniewicz, A., Borysławski, K. 2012: Mumia na receptę, Wiedza i Życie 2/926, 58-61

Urbanik, A., Chrzan, R., Wojciechowski, W., Szymańska, H., Babraj, K., Czubak, A. 2001: Badanie radiologiczne mumii egipskich - doświadczenia własne, Polski Przegląd Radiologii 66, 79-83

Urbanik, M., Rzepiela, A. 2002: Mumia cenniejsza niż złoto, Farmacja polska 58, 572-579 


\section{ÉTUDES et TRAVAUX XXXI / 2018}

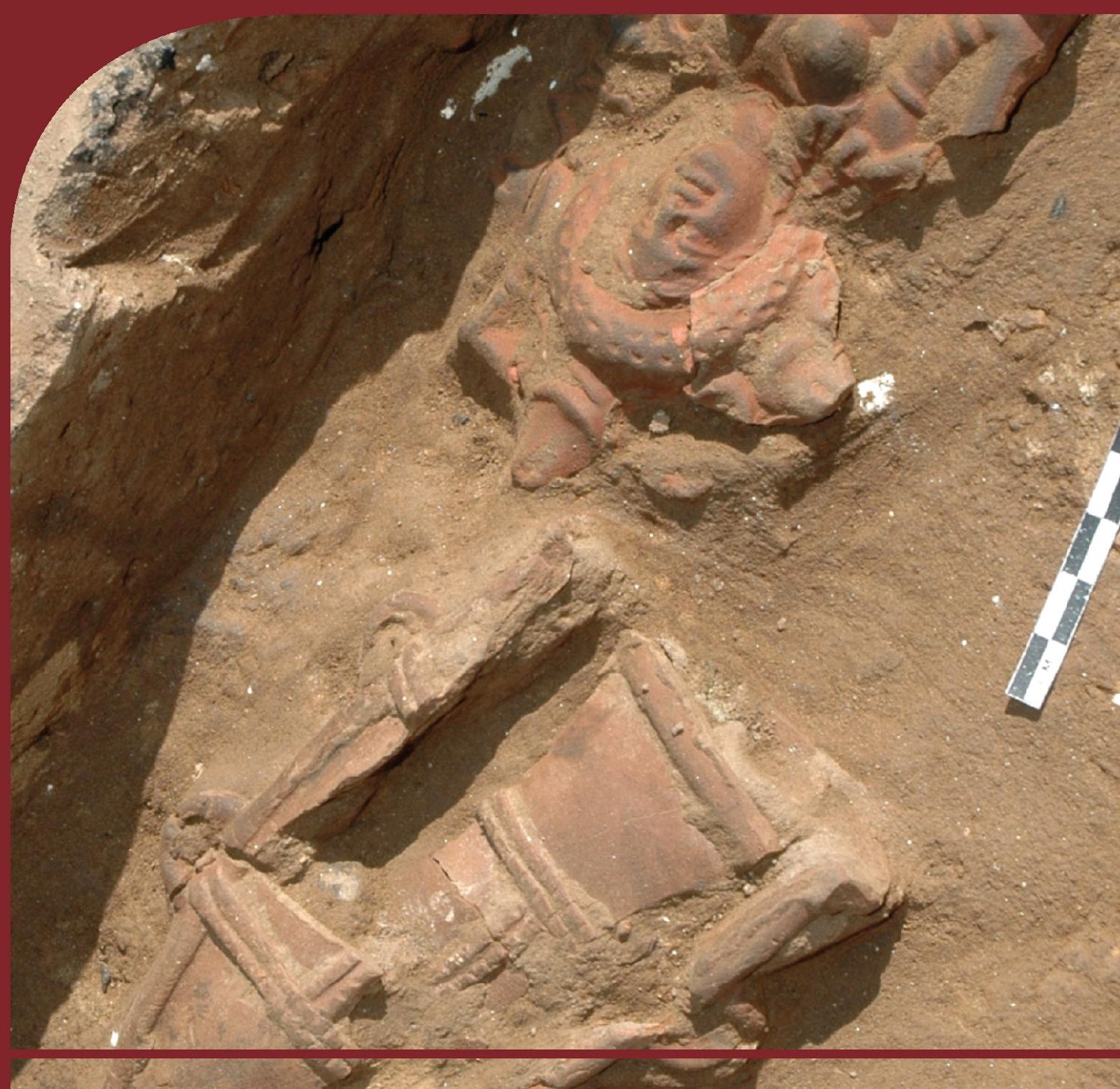

Institut des Cultures iyréditerranéennes et Oilentales FORIKSiO - de PAcadémie Polonaise des Sciences DS PA 


\section{COMITÉ DE RÉDACTION SCIENTIFIQUE}

Maciej Makowski - rédacteur en chef

Jadwiga Iwaszczuk - rédacteur

Mariusz Drzewiecki - sécretaire de la rédaction

Karol Myśliwiec - rédacteur thématique du volume

CONSEIL SCIENTIFIQUE DU JOURNAL

M. Kobusiewicz (IAE PAS, Warszawa), E. Laskowska-Kusztal (IMOC PAS, Warszawa)

D. Michaelides (University of Cyprus, Nicosia)

J.Ch. Moretti (IRAA-MOM, Université de Lyon 2/CNRS)

D. Raue (Ägyptisches Museum der Universität Leipzig), P. Reynolds (ICREA, España)

D. Welsby (British Museum, London)

\section{COMITÉ SCIENTIFIQUE DE LECTURE}

H.D. Baker (University of Toronto), P. Ballet (ArScAn-ESPRI, Université Paris Nanterre),

N. Beaux Grimal (IFAO, Cair/Collège de France, Paris), A. Dodson (University of Bristol),

L. Gabolde (CNRS), C. Gobeil (Egypt Exploration Society, London),

J. Holaubek (Institut für Ägyptologie, Wien), S. Ikram (American University in Cairo),

K. Innemée (Universiteit Leiden), Ch. Leitz (Universität Tübingen),

A. Loprieno-Gnirs (Universität Basel), Ch.E. Loeben (Museen für Kulturgeschichte, Hannover),

S. Ortisi (Universität München), A. Peignard-Giros (HiSoMA-MOM, Université de Lyon 2/CNRS),

E. Rova (Università Ca' Foscari Venezia), A. Sasson (San Diego Natural History Museum),

G. Schreiber (Eötvös Loránd University, Budapest), E. Teeter (University of Chicago),

Y. Tristant (Macquarie University, Sydney), V. Vaelske (independent researcher),

V.W.J. van Gerven Oei (independent researcher), H. Vymazalová (Charles University, Prague),

K. Winther-Jacobsen (Danish Institute at Athens),

J.A. Ostrowski, E. Papuci-Władyka, J. Śliwa (IA JU, Kraków),

R. Czerner (WUST, Wrocław), A. Ćwiek (IA AMU, Poznań),

K. Domżalski (IAE PAS, Warszawa), M. Pinker (FOS UW, Warszawa),

Ł. Niesiołowski-Spanò (IH UW, Warszawa), M. Gawlikowski (PCMA UW, Warszawa), K.O. Kuraszkiewicz (DE FOS UW, Warszawa), M. Barwik, P. Dyczek, W. Godlewski,

S. Rzepka, J. Żelazowski, A. Niwiński (IA UW, Warszawa)

\section{RÉDACTION TECHNIQUE}

Maciej Makowski, Jadwiga Iwaszczuk

CORRECTION LINGUISTIQUE

Jo Harper 
ÉTUDES et TRAVAUX

XXXI 
INSTYTUT KULTUR ŚRÓDZIEMNOMORSKICH I ORIENTALNYCH POLSKIEJ AKADEMII NAUK

\title{
STUDIA i PRACE
}

XXXI

\author{
gO IKŚiO \\ ESA PAN \\ WARSZAWA \\ 2018
}


INSTITUT DES CULTURES MÉDITERRANÉENNES ET ORIENTALES DE L'ACADÉMIE POLONAISE DES SCIENCES

\section{ÉTUDES et TRAVAUX}

XXXI

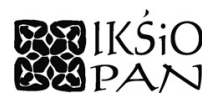

VARSOVIE

2018 
Publication scientifique financée dans le cadre du programme du Ministre de la Science et de l'Éducation Supérieure « Programme National de Développement de l'Humanistique » pour les années 2016-2021 (projet $n^{\circ} 3 \mathrm{bH} 15009983$ )

\title{
Harodowy PROGRAM ROZWOJU HUMANISTYKI
}

\author{
Copyright $($ ) \\ Instytut Kultur Śródziemnomorskich i Orientalnych PAN \\ et les Auteurs \\ Warszawa 2018
}

ISSN 2084-6762

(avant $2011: 0079-3566$ )

e-ISSN 2449-9579

Version première en papier, imprimée en Pologne - 150 copies

Version électronique accessible sur http://www.etudesettravaux.iksiopan.pl

Édition: Polskie Towarzystwo Historyczne et Wydawnictwo Neriton, Warszawa

Conception générale de couverture : J. Iwaszczuk Photo de couverture : P. Moser (C) Schweizerisches Institut für Ägyptische Bauforschung und Altertumskunde in Kairo

(terre cuites d'Aswan/Syene) 


\section{Table des matières}

KAROL MYŚLIWIEC

$(E T=E t u d T r a v / 50) \times 30$

HASSAN Aglan

Hatshepsut and the Apis Race: New Quartzite Relief Fragments

from Dra' Abu el-Naga

Amgad Joseph

Divine Wrath in Ancient Egypt

Amgad Joseph

Pain Infliction, Inflictors and Healers in Egyptian Religious, Magical

and Literary Perceptions

MirosŁaW BarwiK

New Dipinti in the Birth Portico of the Hatshepsut Temple at Deir el-Bahari

KrzyszTOF BorysŁaWsKi, ANNA NiwiŃSKA, ANDRZEJ NiwiŃSKI,

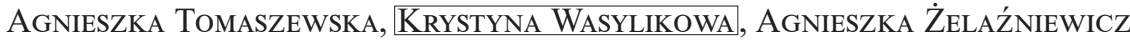

A Bulb of Narcissus on the Egyptian Mummy from University

of Wrocław Collection

LINDA CHAPON

Some Reliefs Representing the King in the Heb Sed Robe Discovered in the Henket-Ankh

Philippe Guillaume

Debunking the Latest Scenario on the Rise of the Pork Taboo

Mariola Hepa

A Clay Gladius Scabbard from Area 13c in the Ancient Roman Town of Syene

Emanuele E. Intagliata

Pinpointing Unrest at Palmyra in Early Islamic Period. The Evidence from Coin Hoards and Written Sources 
KATARZYNA KAPIEC

The Sacred Scents: Examining the Connection Between the ' $n t j w$ and $s f \underline{t}$ in the Context of the Early Eighteenth Dynasty Temples

DOMINIKA MAJCHRZAK

Remarks on the Iconographic Motif of the Birdman in Mesopotamian Glyptic Art of the Third Millennium BC

KAROLINA PAWLIK

Stone Artefacts from Late Roman Occupation Phases in Nea Paphos

ABRÉVIATIONS 
THE VOLUME IS PUBLISHED TO CELEBRATE

THE $50^{\text {TH }}$ ANNIVERSARY

OF THE

ÉTUDES ET TRAVAUX

ESTABLISHED IN 1966 